\title{
Mobile phones, non-human agents at the service of assisted reproduction: monitoring and gendered dual allegiance
}

Telefones celulares, agentes não-humanos ao serviço da reprodução assistida: monitoramento e dupla fidelidade generificada

\author{
Véronique Duchesne' \\ https://orcid.org/0000-0003-2428-7782 \\ veronique.duchesne@ceped.org \\ I Université de Paris - Paris, France
}




\begin{abstract}
For sub-Saharan women enrolled in a protocol for assisted reproductive technology (ART), the use of mobile phones entails dual allegiance: toward the services of reproductive medicine and toward their transnational family. Indispensable for medically monitoring women's reproductive bodies, the mobile phone enters the process for producing female gametes and contributes to the gender asymmetry typical of biomedicalized procreation. It is also used to maintain contacts with transnational family members who, from a distance, obtrude in the woman's reproductive life. The use of mobile phones extends biomedical power over the woman's body into her everyday life and the normative power of her transnational family into reproduction. Paradoxically, the mobile telephone allows collateral relatives to support the woman seeking reproduction assistance while also "hypermedicalizing" the woman's daily life. Also paradoxically, this everyday companion is conductive to individual autonomy while also being used for new forms of surveillance and control. The data come from fieldwork conducted in the greater Paris area between 2011 and 2013 within a network of ART professionals and their patients.
\end{abstract}

Keywords: mobile (cell) telephones; medically assisted reproduction; actor-network theory; gender.

\title{
Resumo
}

Para as mulheres subsaarianas inscritas em um protocolo de tecnologia reprodutiva assistida (TRA), o uso de telefones celulares implica dupla fidelidade: para com os serviços da medicina reprodutiva e para com sua família transnacional. Indispensável para o monitoramento médico dos corpos reprodutivos das mulheres, o telefone celular entra no processo de produção de gametas femininos e contribui para a assimetria de gênero típica da procriação biomedicalizada. Também é utilizado para manter contatos com membros da família transnacional que, à distância, intrometem-se na vida reprodutiva da mulher. $\mathrm{O}$ uso de telefones celulares estende o poder biomédico sobre o corpo da mulher em sua vida cotidiana e o poder normativo de sua família transnacional para a reprodução. Paradoxalmente, o telefone celular permite que parentes colaterais apoiem a mulher em busca de assistência reprodutiva ao mesmo tempo que "hipermedicaliza" a vida diária da mulher. Também paradoxalmente, esse companheiro cotidiano é condutivo à autonomia individual ao mesmo tempo que é utilizado para novas formas de vigilância e controle. Os dados vêm do trabalho de campo realizado na região da Grande Paris entre 2011 e 2013 dentro de uma rede de profissionais de TRA e seus pacientes.

Palavras-chave: telefones (celulares) móveis; reprodução medicamente assistida; teoria do ator-rede; gênero. 
Since the end of the 20th century, geographical mobility for assisted reproductive technology (ART) has grown exponentially worldwide because of technological and scientific innovations along with increased connectivity and the globalization of telecommunications. Reproductive technologies are emblematic of the transformation of global society (Franklin; Ragoné, 1998; Inhorn, 2002; Knecht; Klotz; Beck, 2012). Among the many forms of technology now used to make parents (Thompson, 2005), information and communication technology (ICT) has been largely overlooked. Since the beginning of the new millennium, cellular phones have become the principal personal means of communication (Allard, 2010). Mobile telephony is both global and individual.

Considering technological devices to be "actants" (agents that act) within a network, actor-network theory proposes exploring how humans and "non-humans" interact within a network (Houdart; Thiery, 2011). My intention herein is to examine mobile telephones (cell phones) as a nonhuman agent in medically assisted reproduction, a field that is, of course, inseparable from the "gender order" (Löwy, 2006). This article intends to contribute to the study of how ICT (specifically, mobile phones) take part in constructing a gender hierarchy. ${ }^{1}$

In France, the Bioethics Law of August 2004 (as modified in 2011) set the conditions for assisted reproduction. It clearly stipulated who might apply: the man and woman forming the couple had to be alive, of childbearing age, and married (or else provide proof of having lived together for at least two years). Both must consent to assisted reproduction. Since then, the requirement of living together for two years has been abolished. An act of 2 August 2021 has opened medically assisted reproduction to female couples and single women. ${ }^{2}$

My fieldwork began in Île-de-France (the greater Paris area) where I conducted research with gynecologists and several women patients born

1 My research - part of the program "Stérilité et recours à l'assistance médicale à la procréation dans un contexte de mondialisation (Douala, Paris, Pretoria)" - was funded by the French National Research Agency (ANR). My thanks go to the assisted reproduction professionals (doctors, nurses, secretaries) and their patients who confided in me during fieldwork. I am also grateful to reviewers for their precious comments. The original version of this article was translated from French by Noal Mellott, Omaha Beach, France, who has also line-edited the final version.

2 With full coverage (100\%) under Social Security Health Insurance for infertility treatment available to women before their 43rd birthday. The patient may have a maximum of six inseminations or four IVFs. 
in countries south of the Sahara. The latter were selected regardless of their administrative status: some were immigrants while others were tourists. ${ }^{3}$ Those who reside and work in France (with the appropriate permits) are covered $100 \%$ under Social Security's Health Insurance, whereas those who live in an African country and come to France on a short-term "tourist" visa have to pay for $\mathrm{ART}^{4}$ a difference with an enormous economic impact. All these women had their own cell phones, the small "nonhuman" device on which this research focused.

Following a description of my fieldwork and methodology, this article draws attention to the ways that mobile telephony takes part in the control of women's reproductive bodies (not just African women, in fact) and how it acts on the practice of medicine. Attention will then be shifted to the normative power that members of sub-Saharan transnational families exercise via mobile phones over women who want to bear a child with the assistance of medical technology.

\section{Methodology}

My fieldwork was conducted in Île-de-France between 2011 and 2013 within a network of professionals specialized in ART and their patients. This network grouped medical biologists from a private laboratory in Paris, gynecologists in private practice in Paris and in departments to the east and north of Paris (Val-de-Marne and Seine-Saint-Denis) and the staff of a private nonprofit hospital in Paris. ${ }^{5}$ I adopted an inductive approach involving direct observation and in-depth interviews. The hospital's ethics committee authorized my

3 Another administrative status is "irregular situation". However, a decree of 17 October 2011 had put an end to the State Medical Aid (AME in French) for assisted reproduction to persons in an "irregular situation: women had to abruptly abandon assisted reproduction.

4 Many studies exist on what was first called "reproductive tourism" and is now referred to as "cross-border reproductive care".

5 This hospital which had been approved for ART in 1997. In France, assisted reproduction centers are approved by the Regional Health Agency (ARS) after receiving an opinion from the Biomedicine Agency. 
research and my presence during consultations under condition that patients consent. Each patient filled out a consent form beforehand. ${ }^{6}$

I observed consultations in gynecology and ultrasound examinations, approximately a hundred, between March 2011 and June 2012, mostly at two locations: the semi-private hospital in Paris and the private medical office in a town in Seine-Saint-Denis. At the hospital, I also observed several "preliminary appointments" (which both members of the couple had to attend) for registering the application for ART. From January 2012 till June 2013, I attended monthly staff meetings (in the evening) at the hospital. Observations of laboratory appointments for tests (blood work, sampling, embryo transfers, etc.) provided me with an overall view of the process of medically assisted reproduction.

This ethnographic research is based on in-depth interviews embedded in my fieldwork and, thus, in the process of providing ART to patients. The effectiveness of in-depth interviews very much depends on the place and timing. I carried out interviews with five doctors (three women and two men) at their workplace. About thirty interviews were conducted with their patients born in sub-Saharan Africa. Prior to each interview, I presented my research and pointed out that my usual place of fieldwork was West Africa. After answering any questions, mobile phone numbers were exchanged - each patient had her own cell phone. I would then call them back, and we would agree on a time and place for the interview, which would last between 45 minutes and 2.5 hours. Most of these interviews took place with the woman alone and in a medical setting (in an office left at my disposal in the hospital, in the gynecologist's second office or in the private health center's small ultrasound room). Four interviews took place in patients' homes. Before the start of each interview, I requested the interviewee's consent and permission to record.

In all, twenty-one women and seven heterosexual couples agreed to be interviewed. Except for a Ghanaian couple, all had been born in a French-speaking country: in West Africa (Benin, Guinea, Mali, Niger, Côte d'Ivoire, Senegal, Togo), Central Africa (Cameroon and Republic of Congo) and the Indian Ocean

6 The consent form specified that the person had been informed of the professional secrecy surrounding research, that the survey was independent of health establishments and did not involve any medical act, and that the results may be used in scientific publications. Patients also have a right of access to their data at any time during the research program. 
(Union of the Comoros). All the women (save one) were, at the time of the interview, working. Four worked in Africa (a bank employee, merchant, civil servant, and manager) and had taken time off for ART. The seventeen others were residing in France and managed with difficulty to harmonize the requirements of ART with their jobs - a situation not unlike that of French women (Hertzog, 2014). Their jobs were in cleaning services, child or home care, social work, hairdressing, human resources, hotels, sales, etc. However, their educational backgrounds varied widely: three had a postsecondary degree whereas one had never had schooling and had difficulty speaking French.

To protect the anonymity of interviewees, I have altered their first names, having chosen a new name that suggests the country of birth and religion. Their marital status is indicated by the addition of "Mrs." before this modified name.

\section{Mobile telephones and monitoring patients}

During the first appointment at the hospital, the couple received a sixteen-page information package, which mentions the use of the telephone several times. On the fourth page, for example: "Before IVF, you must make an appointment 1) with the medical biology team at the laboratory at [telephone number]; and 2) with an anesthesiologist at the hospital before the start of your stimulation. For that, contact the secretary's desk at [telephone number]. (Waiting time for an appointment: one month)." The following pages describe the IVF cycle's four steps. The first, "ovarian stimulation", involves "blocking the spontaneous cycle and stimulating the ovaries [which] prevents ovulation and therefore egg loss, before retrieval", while "hormonal stimulation will allow for follicle growth and maturation". According to the booklet, "Instructions will be communicated to you by the ART secretary's office, which will phone you around 3 p.m. It is, therefore, indispensable that you can be reached by telephone. At that time, you will be informed of the stimulation dose to use for injections in the evening and the following days and of the date for the next control. Ovulation is triggered when the ovarian follicles have reached a certain degree of development, i.e., when there are at least three 17-18 mm follicles with the correct doses. The instruction will then be for an injection, at a precise time that has to be observed; the retrieval technique has to be performed 35-38 hours after this injection." For the 
second step, "oocyte retrieval and sperm collection": oocyte retrieval requires "day hospitalization in our establishment". About the third step "fertilization and culture of the embryos in the laboratory": "A medical biologist from the ART laboratory will phone every day to tell you about the growth of the embryos. You will be informed [by phone] by the laboratory of the day and time for the embryo transfer. The evening before the transfer, you will start the treatment (via the vagina) and [continue it] until the results of the pregnancy test." The final step, "embryo transfer", takes place in the hospital, usually two to three days after the retrieval.

As we notice, the information folder foresees, from the very start, the telephone as an indispensable "agent" in the IVF protocol. The first contact for setting an appointment always take place by phone, as the medical secretary enters communication with a patient from a socially, and sometimes, geographically, distant world. During the treatment, the phone is used to transmit instructions to patients about the production of oocytes. Thus, medium is also used to announce the suspension of a treatment, an announcement that signals a failure and dashes the couple's hopes.

\section{An asymmetric phone conversation}

Whether in the hospital or in private practice, the secretaries were constantly on the phone. Researchers have paid little attention to the work of these women in telephone communications. From the outset, when an appointment was to be set, the first contact was by telephone. This could be a problem for both the caller and the secretary who answered. As I waited in the entrance of the private medical center in Seine-Saint-Denis (in December 2012), the secretary was in communication with a patient. She finished by raising her voice: "IVF and insemination are not the same thing. We need your serology, sir." After hanging up, she told me he was calling from Gabon and that this exchange had exhausted her. Telephone communication between two people who do not know each other tends toward problems of misunderstanding owing to the factors that intervene in long-distance communications (rate of speech, accent, vocabulary, not to mention intercultural factors). Such long-distance communications were laden with differences in perception and understanding between the two parties; the distance (not just geographical) between them could not be fully bridged. 
In this "reproscape" (for "reproductive landscape": Inhorn, 2011), medical secretaries talked over the phone with people overseas who wanted to make an appointment or sometimes set up an ART protocol before their arrival in France. Sharing the French language was not sufficient for intelligibility. The technical vocabulary (insemination, semen analysis, serology, etc.), used bluntly by the secretaries, was unfamiliar to these persons who were turning toward medicine for help with conceiving a child. The medical vocabulary so fluently used by the secretary was not familiar to these sub-Saharan patients, at least not at the start. All the other ART professionals (gynecologists, biologists, and nurses) used the same jargon to talk about treatments (long/short protocol) and techniques (insemination, oocyte retrieval, etc.). They shared a professional culture unfamiliar to the patients. Some patients asked a sister or sister-in-law, who was working in the field of medicine, to make the appointment for them. This relative, who shared this professional culture, was more familiar with the procedure for scheduling an appointment. He or she knew the right time to call for an appointment, the hours of consultations, the periods of breaks.

While the telephone allowed for remote communication and delegation, it paradoxically maintained the asymmetrical relationship between health professionals and "lay persons", in particular their patients. These women were in a position of strong dependence on, or even subordination to, ART professionals.

\section{The mobile phone at the service of gamete production}

The assisted reproduction protocol started when the patient informed the secretary - over the phone - of the first day of her menstrual cycle ("Day 1"). There were then three sociotechnical sequences for monitoring and evaluating the quality of ovulation induction: the morning blood test to check and dose the estradiol level (for measuring the degree of follicular maturity), the endovaginally pelvic ultrasound (to count the ovarian follicles and measure the endometrium's thickness) and, finally, the analysis of the results by the doctor and the transmission by telephone of instructions (adjustment of the treatment, date of ovulation induction, scheduled sexual intercourse, intrauterine insemination or oocyte retrieval, or suspension of a stimulation cycle). This third sequence for "monitoring" figured on the schedule of hospital practitioners. The women patients came in the morning for a blood test and ultrasound and 
were then immediately contacted to adjust their current treatment in line with the latest results received via the Internet, sometimes just a few minutes before the phone call. When I arrived at the hospital for my first day of field work at 1:20 p.m. (in March 2011), the secretary, phone in her hand, was passing on the instructions to patients, while the doctor stood next to her. First call: "Continue and add an injection of [name of the drug for regulating the lutenizing hormone]. Saturday morning, come in for blood work." Second call: "He has to come to the laboratory for semen collection at 8 a.m." The last call at 2 p.m.: "Starting on Sunday, switch to three pills a day, morning, noon and evening, intravaginally. [The secretary in an aside to the doctor: In my opinion, she's taking them orally instead of intravaginally." As the instruction booklet insists, this first step requires a high degree of availability on the part of the woman: it was indispensable that the ART services could reach her by phone.

By following the women patients in all their movements and conveying the doctor's instructions in real time, the mobile phone took part in governing these women's reproductive bodies. By facilitating and accelerating the transmission of medical instructions, it entered the process of producing female gametes and contributed to the gender asymmetry that characterizes this step of medically assisted procreation. In the 1990s, American feminist anthropologists drew attention to (and even criticized) this medicalization of the female reproductive body (Franklin; Ragoné, 1998; Rapp; Ginsburg, 1995). Since then, several social science studies have highlighted the gendered dimension of reproductive techniques (Inhorn, 2002; Tain, 2013). This asymmetry stands out during "gamete collection" (Löwy, 2006, p. 36), prior to fertilization in a test tube, since the prolonged hormonal stimulation and surgical retrieval of the oocytes are, for women patients (even if they are fertile), stressful, painful procedures that are not without health risks. While the word "collection" used for male gametes does not particularly emphasize a technical intervention, the word "retrieval" (or "puncture") used for oocytes refers to a surgical action performed on a woman's passive body. ${ }^{7}$ During interviews, several women who were coping with their husband's infertility expressed, when the husband was not present, their feelings about this gender asymmetry of ART.

7 For this reason, the French biologist Hélène Rouch (2011) has preferred using the word "extraction". 
Ovulation was "triggered" with an injection of human chorionic gonadotropin (hCG). This injection was usually administered at home, by the patient, a nurse, or the spouse (in a few cases, such as that of a Congolese woman whose husband was a nurse). For the doctor, the challenge was to "pull the trigger" at the right time: too early or too late would reduce the chances of success, and too late might even increase the risk of ovarian hyperstimulation. During this phase of remote monitoring, medical prescriptions were immediately transmitted by telephone, and patients had to understand the instructions right away. This could lead to complications as in a Malian couple that had given the mobile phone number of the husband, who then had to relay the instructions to his wife.

Mobile telephony has introduced new forms of surveillance and control. In the case of ART, the mobile phone has increased the capability and performance of biomedical power by allowing for reaching the female reproductive body wherever it is. The mobile phone makes it possible to contact a patient anywhere anytime, unlike a landline telephone which is assigned to a fixed location. Through the mobile phone, the woman's biological body is integrated into the biomedical protocol for the purpose of reproduction.

\section{The mobile phone for announcing the suspension of the protocol}

The instruction to stop ovarian stimulation was also usually conveyed over the phone, even though the information booklet did not inform patients of this. At the Paris hospital (March 2011), during a call for monitoring the patient, the doctor asked the secretary to pass the phone so he could speak directly to the patient, who was starting her treatment in Algeria: "Your dosage is not right. The progesterone is too high. Dr. N. is going to receive you. You must cancel the treatment. I know that's the reason you're coming, but a puncture will serve no purpose." Given his legitimacy, the doctor's voice carried more weight than the secretary's for announcing that the treatment was interrupted. This interruption was presented as a termination ("cancel", "stop"). Patients found it hard to accept this "remote" announcement by a telephonic voice. Elizabeth, who received me on a Monday in June 2011, her weekly day off, in the apartment shared with her sisters (in a town in Val d'Oise), began by talking about her recent experience in a hospital (in the north of Val d'Oise) that had "shocked" her: "Every time they do an ultrasound on me, they tell me they don't see anything. The last time, 
the midwife was worked up, she said that she didn't see anything, that, my case was hard any way, that I didn't have enough oocytes and that they wouldn't be able to do the retrieval. When I got to work in the afternoon, she announced the news [...] directly, by phone. She called to tell me to stop the treatment, that it was no use continuing: "It's necessary to make an appointment with your doctor." Elizabeth cried throughout the interview, which lasted more than one hour. This 34-year-old was born in Congo, had Italian nationality through her father and grew up in Africa till coming to France in 2006. When I left her, she told me she was waiting for her next menstrual period to start a new cycle of ovarian stimulation. Her life was organized around the biological rhythm of her reproductive body.

The announcement to suspend the protocol closed a phase characterized by uncertainty (about whether ovarian stimulation would induce the growth of enough follicles) and by a huge personal investment based on hope. Unlike during a face-to-face meeting, the mobile phone transmitted instructions without heed of any feedback from the respondent. This announcement had serious consequences on the women: they would have to wait for the next (or even next after) menstrual cycle, while their ovaries "rested" from stimulation. Only then could the protocol be resumed. For older patients, suspending the protocol meant not only waiting to resume it later on but also waiting while their bodies and reproductive potential were ageing.

The interruption of the protocol was often announced following the ultrasound exam, which, carried out in a cramped room, lasted about fifteen minutes. During this exam, a triangular relationship formed between the patient, the gynecologist (a woman) and the imaging device's screen. The gynecologist focused on the screen, not on the woman or her nonverbal reactions. For ART, this exam served to monitor how the ovaries were "responding" to stimulation: the doctors talked about a "poor response" when no more than four mature follicles developed. The follicles were counted and measured, and the endometrium gauged, to evaluate the likelihood of success for the protocol and foresee eventual risks for the patient. Some patients associated the ultrasound exam with a monitoring of pregnancy and not with the development of follicles (which they never name). This exam let these women see a glimmer of hope, while the announcement over the phone to "stop" treatment made them hear a message of failure. These two "nonhuman actants", ultrasound imagery and mobile phones, intervene antagonistically. 
The mobile telephone had a performative role both in producing female gametes and (temporarily) stopping the patient's plans for conceiving a child. The ART protocol entails fast reactions (to start or suspend a treatment, prescribe an additional exam, etc.), a reactivity with consequences on both the medical staff and patients. Paradoxically, the mobile telephone, this everyday companion, hypermedicalized the woman's daily life. It transmitted to women in real time medical prescriptions or announcements - instructions that, without the physical proximity of a doctor-patient relationship, left an abrupt impression on patients. ${ }^{8}$

Although the mobile phone allowed for day-after-day exchanges of information with the medical staff, it also served to maintain a network of relations with relatives and family members.

\section{The family's remote control via mobile phones}

Mobile phones, now affordable, have become the principal means of long-distance communications for Africans on the continent or in the overseas "diasporas" (De Bruijn; Nyamnjoh; Brinkman, 2009). The phrase "transnational family" refers to a (more or less) extended family with members dispersed around the globe (Le Gall, 2005, Razy; Baby-Collin, 2011). Thanks to mobile phones, these family members are able to maintain contacts despite the distance separating them. As personal, portable, and pedestrian devices (Ito; Okabe; Matsuda, 2005), mobile phones enable family members to keep in touch regardless of their location. Africans living in France, who used to have to take account of the high cost of calling back home, can now talk with their families on a regular basis (Mattelart, 2009; Pasquier, 2001).

In Africa, exchanges by telephone have become part of a "culture of contact" (Horst; Miller, 2006), wherein what is said might be less important than keeping in contact. Phone conversations update relationships (De Bruijn; Brinkman, 2011). They, especially long-distance exchanges with transnational family

8 A contrasting example: the quality of the future relationship between patient and oncologist strongly depends on the communication that takes place during the consultation when the diagnosis is announced (Estival, 2009). 
members, are laden with affects. But the mobile phone also extends the family's normative control over reproduction.

\section{Constant contacts despite distance}

Although the telephone might not make up for the want of information and communication that results when the parties are separated by a long distance, it does act like a "social glue" for maintaining connections between transnational family members (Vertovec, 2004). This held for the women requesting ART in Île-de-France: they remained directly connected to family members via their mobile phones.

When I visited Mrs. Aïssatou at the women's emergency shelter where she was staying in Paris (May 2013), I heard the social worker at the reception desk refer to her, in a friendly tone of voice, as the "phone booth". Mrs. Aïssatou had two phones, which rang constantly: the one connected her to her contacts in France; and the other, to her family in Guinea. She thus had connections with a vast network both in the country she had left (in order to escape pressure from her in-laws) and in France, where, by herself, she was pursuing her quest to bear a child. Her husband, after leaving his gametes, had gone back to Guinea to work. Having left her job and family and sold her possessions to carry out the couple's plans for bearing a child, Mrs. Aïssatou explained to me how important it was for her to keep in touch with her network of friends and to be reachable by the hospital, since she was no longer living with a relative of her husband, where letters from the hospital were still being sent. To be fitted out with a mobile phone is essential for anyone on the move and for persons in an unstable situation (Diminescu, 2002).

According to Ma Mung (1993 apud Gonin, 2010, p. 13), "the individual of the diaspora [has an] imperative of ubiquity in his/her way of thinking of themselves in space, they have to [...] perform the double operation of situating themselves in two different places." The idea of a "double presence", or even multiple presence, refers to this "multisite investment" (Diminescu, 2005) - to the ties that immigrants (and anyone who moves about) maintain with families or close networks (which might not necessarily be in the place of origin). Given that these patients could talk almost for free (or even see each other via WhatsApp, for instance), this form of communication has shifted from being a means for 
making up for an absence to a means that represents a way of living together apart. Ties between patients and their families were strong, and, thanks to this new communications technology, were cultivated, practiced, reenacted almost daily. The mobile phone accompanied the patient who owned it and her movements from sunrise to sunset. It thus augmented the aforementioned "imperative of ubiquity". Regardless of where patients might be, communication via a mobile phone could make present someone who was physically absent.

Phone conversations with extended family members are a priority for those who have left their homeland, but they can also become a constraint. Given the massive use of mobile phones, any situation (whether in a private, public, or professional space) is liable to become an occasion when family members intrude (Licoppe, 2010), "dropping in" through their phone calls at any time.

\section{The family's normative control over the woman's reproduction}

The study of telephone communications among transnational family members should not overlook the context of social interactions, nor turn a blind eye to forms of control or even domination. When I met Mrs. Fatoumata at the private medical center in Seine-Saint-Denis (in December 2012), she was about to return to her homeland, Mali, after working in Chad. She came to see the gynecologist at the same time as her pregnant sister, who was married and living in France. At the end of the appointment, as I was starting to tell them about my research, she received a call on her mobile phone and told me right away, "It's my mother in Bamako. She knew my appointment was at 4 P.M. Since I haven't called her yet, she's called me." For reasons of cost, it is usually the person far from the family who calls back home, but the reverse occurred in this case. Having married a month ago, Mrs. Fatoumata explained that her mother and her in-laws were impatiently waiting to hear that she was pregnant. The mobile phone enabled her mother to follow her medical appointments in real time from Mali. This long-distance monitoring, tinted with affection according to Mrs. Fatoumata, attested to her family's impatience. Normative and gendered pressure was thus brought to bear on her: a newly married woman must "give a child to her husband" fast (Duchesne, 2014). 
One property of a phone call is its immediacy: it summons the person to answer (Green, 2002). The person who takes the call has a moral duty to be "reachable". In intrafamily relations, a mobile phone is a means not just of communication but also of surveillance (Horst, 2006). It reinforces potential surveillance by the family back in the homeland. It does not just strengthen interpersonal relationships but also consolidates the individual's status as a family member. Calls from parents living in Africa could be very unsettling because they were so disconnected from life in France. Owing to the personalized nature of the relationship, the mobile phone might unsettle a married woman already under stress owing to her couple's infertility, as we see in the following case. During the interview at her home (in a town in Val-d'Oise in July 2011), once her husband had left for work, Mrs. Mariama explained to me: "One of his cousins [a woman] called to tell me to come back home [to Senegal] and try traditional remedies. I was shocked. I told him [her husband] about it, asking him why his cousin was calling me, why did she think that I, the woman, had to be treated?" The deeply gendered norm of presuming that only the wife could be infertile was even more offensive since the medical diagnosis, in this case, concluded male infertility.

Unlike a landline phone, a mobile phone is personal and has a much higher potential for discretion and individualization. It created a communication network that the spouse could not control. The parents who lived far away could, via the phone, personally influence or even compel the person whom they were calling to act. The pressure brought by kin from afar was strong enough to make women want to try anything to bear children, strong enough to make husbands accept the family's solution, such as finding a second wife.

During an interview in the private gynecologist's office (in Seine-Saint-Denis in May 2011), Mrs. Anta, who had come to France in 2004 after her marriage in Mali, told me that her husband was constantly receiving calls from his mother asking him to come back home to take a new wife: "Yesterday, his mom called again to ask what date he had set to come back to marry." Mrs. Anta and her husband came from the same Soninke village, and the husband's family was impatiently awaiting the birth of a son to perpetuate the lineage (under customary law, descent is patrilineal). Her husband seemed to be withstanding this family pressure, since he decided to put off his trip till the end of the year. But Mrs. Anta told me she was preparing for the worse: repudiation. 
Phone conversations with transnational family members could represent a threat for the ART procedure instead of an encouragement because these women did not talk about their treatment with their parents. The father and mother could not understand why anyone would turn to medical assistance for reproduction, since such techniques are little known (and seldom available) in the homeland (Bonnet; Duchesne, 2016).

\section{Long-distance emotional support}

Disconnected from the speaker's body and facial expressions, a voice over the telephone has the power of arousing feelings in the listener owing to its intensity, timbre or the words used. Mrs. Ama, born in Côte d'Ivoire, had come to France at the age of twelve with her mother. She began the interview (carried out in the biology laboratory in Paris in July 2011, after the couple's consultation) by telling me: "I come from a big family... very big. Let's say... 17 girls and 14 boys" of the same father. At different points, she related the words of her father (who was living in Côte d'Ivoire): "I have even had my father on the phone telling me, 'I'm fertile, your mother's fertile, there's no reason you're not.' [...] When my father says, 'The real treasure is your children, your own, not the children of your brothers or the children ofyour sisters', he's saying, 'You see, my treasure, my own, is you. So, ifyou want to have yours later, it'll be your own children. They're the ones who'll take care of you later, not your brothers' or sisters' children.' When your father says that, you hang up and cry."

The relation over the phone is "heavily laden with emotions" (Pasquier, 2001). When the person lived far from relatives, the telephone helped to make up for what was "wanting" in the relationship. In this context of geographical remoteness, what passes through the voice is more intense than what is conveyed in writing - Sayad (1985) already pointed this out about the audio cassettes that African migrants recorded and sent to their family in the homeland. Words over the phone convey emotions and create new forms of intimacy.

Several women told me about the support and comfort conveyed by relatives over the phone. Mrs. Monique, who came to France during her vacation for her first IVF, told me she received supportive calls every day from family and friends in Cameroon: "Everyone's praying for it to work." Whether Muslim or Christian, patients frequently mentioned praying with a sister or brother over the phone. In these transnational families, "collateral kin" (brothers, sisters, 
and cousins), regardless of their place of residence, were highly implicated in the ordeal of infertility; secrecy was not their concern (Duchesne, 2014).

These women passed very little information about the medical techniques and treatment on to family members over the phone or even to their spouses. Mrs. Aïssatou, whose husband had returned to work in Guinea while she continued the assisted reproduction protocol alone, was waiting for his next business trip to France to tell him that she would be receiving donor oocytes (Duchesne, 2016). She told me, "It's delicate to explain that to him over the phone." Even though the mass media in Africa (in particular radio and television) have started carrying information about ART, these, techniques and reproduction are still very private matters (Bonnet; Duchesne, 2016). The paradox of the mobile phone is that it serves to convey to the patient both instructions from the medical staff and emotional support from members of the transnational family.

\section{Conclusion}

Assisted reproductive technology involves a wide range of professions and techniques and implies a specific form of cooperation between a variety of human and non-human agents. Surprisingly, this nonhuman governance over human bodies is accepted with few questions asked by the governed. For sub-Saharan women following an ART protocol in France, mobile telephony established a double allegiance: to reproductive biomedicine on the one hand, and to the transnational family on the other. It paradoxically contributed to individualization and individual autonomy while playing a part in new forms of surveillance and control.

The explosion of connected objects and of the platforms that distribute information, along with the popularity of mobile applications, is stimulating the growth of a "mobile health" market (m-health or e-health). Development programs are rushing to put mobile phones to use in low-resource countries in Africa and the Indian subcontinent (Al Dahdah, 2014). Anthropology, and more broadly the social sciences, must continue exploring how biomedicine and ICT are working together at both the global and micro (local) levels in order to analyze the social issues related to the changes thus set off and propose to health-care professionals a reflexive view of their practices. 


\section{References}

AL DAHDAH, M. mHealth: l'information de santé ubique? Le Temps des médias, [s. l.], v. 2, n. 23, p. 52-65, 2014.

ALLARD, L. Mythologie du portable. Lassay-les-Châteaux: le Cavalier Bleu, 2010.

BONNET, D.; DUCHESNE, V. Conclusion. Interroger la parenté africaine au regard des techniques de la reproduction. In: BONNET, D.; DUCHESNE, V. (ed.). Procréation médicale et mondialisation: expériences africaines. Paris: L'Harmattan, 2016. p. 231-237.

DE BRUIJN, M.; BRINKMAN, I. "Communicating Africa": researching mobile kin communities, communication technologies, and social transformation in Angola and Cameroon. Autrepart, [s. l.], n. 57/58, p. 41-57, 2011.

DE BRUIJN, M.; NYAMNJOH, F.; BRINKMAN, I. (ed.). Mobile phones: the new talking drums of everyday Africa. Bamenda: Langaa; Leiden: ASC, 2009.

DIMINESCU, D. L'usage du téléphone portable par les migrants en situation précaire. Hommes et migrations, [s. l.], n 1240, p. 66-79, 2002.

DIMINESCU, D. Le migrant connecté: pour un manifeste épistémologique. Migrations Société, [s. l.], n. 102, p. 275-293, 2005.

DUCHESNE, V. Repenser l'alliance matrimoniale avec l'assistance médicale à la procréation en situation migratoire. Enfances Familles Générations, [s. l.], n. 21, p. 135-149, 2014.

DUCHESNE, V. Le chemin du don et ses trois paradoxes. Des femmes africaines et le don d'ovocytes en France. In: BONNET, D.; DUCHESNE, V. (ed.). Procréation médicale et mondialisation: expériences africaines. Paris: L'Harmattan, 2016. p. 73-88.

ESTIVAL, C. Corps, imagerie médicale et relation soignant-soigné: étude anthropologique en centre de cancérologie. Paris: Seli Arslan, 2009.

FRANKLIN, S.; RAGONÉ, H. Reproducing reproduction: kinship, power and technological innovation. Philadelphia: University of Pennsylvania Press, 1998.

GONIN, P. L'énigme spatiale des Subsahariens. Hommes et migrations, [s. l.], n. 12861287, p. 6-15, 2010.

GREEN, N. Qui surveille qui? Contrôler et rendre des comptes dans les relations de téléphonie mobile. Réseaux, [s. l.], v. 2, n. 112/113, p. 250-273, 2002. 
HERTZOG, I. L. Les coûts de l'assistance médicale à la procréation pour les femmes salariées. Les Cahiers du genre, [s. l.], n. 56, p. 87-104, 2014.

HORST, H. A. The blessings and burdens of communication: Cell phones in Jamaican transnational social fields. Global Networks, [s. l.], v. 6, n. 2, p. 143-159, 2006.

HORST, H. A.; MILLER, D. The cell phone: an anthropology of communication. New York: Berg, 2006.

HOUDART, S.; THIERY, O. (ed.). Humains, non-humains: comment repeupler les sciences sociales. Paris: La Découverte, 2011.

INHORN, M. Infertility around the globe: new thinking on childlessness, gender, and reproductive technologies. Berkeley: University of California Press, 2002.

INHORN, M. Globalization and gametes: reproductive 'tourism,' Islamic bioethics and Middle Eastern modernity. Anthropology and Medicine, [s. l.], v. 18, n. 1, p. 87-103, 2011.

ITO, M.; OKABE, D.; MATSUDA, M. (ed.). Personal, portable, pedestrian: mobile phones in Japanese life. Cambridge: MIT, 2005.

KNECHT, M.; KLOTZ, M.; BECK, S. (ed.). Reproductive technologies as global form: ethnographies of knowledge, practices, and transnational encounters. Frankfurt-onMain: Campus Verlag, 2012.

LE GALL, J. Familles transnationales: bilan des recherches et nouvelles perspectives. Cahiers du GRS, [s. l.], v. 5, n. 1, p. 29-42, 2005.

LICOPPE, C. Les apparitions médiatisées et leurs effets performatifs. Le cas des sonneries téléphoniques et la crise de la "sommation". Réseaux, [s. l.], v. 63, n. 5, p. 131-162, 2010.

LÖWY, I. (ed.). L'emprise du genre: masculinité, féminité, inégalité. Paris: La Dispute, 2006.

MATTELART, T. Les diasporas à l'heure des technologies de l'information et de la communication: petit état des savoirs. tic\&société, [s. l.], v. 3, n. 1/2, p. 11-57, 2009.

PASQUIER, D. “La famille, c'est un manque”. Enquête sur les nouveaux usages de la téléphonie dans les familles immigrées. Réseaux, [s. l.], n. 107, p. 181-208, 2001.

RAPP, R.; GINSBURG, F. (ed.). Conceiving the New World Order: the global politics of reproduction. Los Angeles: University of California Press, 1995. 
RAZY, É.; BABY-COLLIN, V. La famille transnationale dans tous ses états. Autrepart, [s. l.], n. 57-58, p. 7-22, 2011.

ROUCH, H. Les corps, ces objets encombrants: contribution à la critique féministe des sciences. Donnemarie-Dontilly: Éditions IXe, 2011.

SAYAD, A. Du message oral au message sur cassette. La communication avec l'absent. Actes de la recherche en sciences sociales, [s. l.], n. 59, p. 61-72, 1985.

TAIN, L. Le corps reproducteur: dynamiques de genre et pratiques reproductives. Rennes: Presses de l'EHESP, 2013.

THOMPSON, C. Making parents: the ontological choreography of reproductive technologies. Cambridge: MIT Press, 2005.

VERTOVEC, S. Cheap calls: the social glue of migrant transnationalism. Global Networks, [s. l.], v. 4, n. 2, p. 219-224, 2004.

Recebido: 21/09/2020 Aceito: 10/08/2021 | Received: 9/21/2020 Accepted: 8/10/2021 